\title{
The Identification of Bugis Dwellings in Kubu Raya District
}

\author{
Basimah, Zahrul \\ DNA Corporation \\ Jalan Prof. DR. Hamka, Pontianak, West Kalimantan, Indonesia \\ basimah.zahrul@gmail.com
}

\begin{abstract}
Pontianak is a city where the composition of its population consists of various ethnic groups which have migrated and participated in establishing the city, one of which is Bugis. Bugis has been recognized as an ethnic group which has successfully accustomed to the local environment and culture but still maintain their own. One of the characteristics of their culture is represented on their dwellings. In Kubu Raya District, there are three Bugis dwellings which were established by the third generation of Bugis descendants. This research concerned in comparing them with the Bugis houses in South Sulawesi, the city where this tribe originated. The method of sample selection was based on the age of the dwellings, the status quo of the owner that must be the third generation of Bugis descendant and there are no significant changes in the dwellings. The results of the study indicate that there are similarities and differences between the samples and the Bugis Houses in South Sulawesi, particularly in terms of their functions, space arrangement, and mass configuration. The mass configuration in the Bugis Houses in South Sulawesi confirms that the social status of homeowners was also found in all samples. However, the differences in the way Bugis in Kubu Raya function and arrange the space proves that there has been an assimilation between the culture of Bugis and Malay. This prompts the Bugis houses in Kubu Raya to have different spaces with the Bugis houses in South Sulawesi and the same space as the house of the local Malay.
\end{abstract}

Keywords: Assimilation, Bugis, Culture, Dwelling, Malay.

\section{Introduction}

Traditional dwelling is a physical reflection of ethnic culture, and this can be seen from its functions, space arrangement, and mass configuration. These aspects of a dwelling reveals the pattern of the building form that is influenced by various factors, one of which is inherited culture from generation to generation. The Bugis tribe is one of the immigrant tribes in Pontianak that has adapted very well to the surrounding conditions, but still able to maintain its cultural identity.

The history about the arrival of Bugis people to Pontianak is mainly associated with the history of the city's establishment itself. Bugis people who came to Pontianak were the followers of the city's founder, Sultan Syarif Abdurrahman. At first, they came just for trading but eventually chose to settle in the city. Those who chose to stay were organized by Sultan to live in the eastern area of the city. On the other hand, the settlement location of migrants who were not the followers of the Sultan was adjusted to the livelihoods they sought. The migrants of Bugis who worked as fishermen, boat craftsmen and coconut farmers were placed at Sungai 
Kakap and Sungai Itik Village (Veth in Listiana, 2006: 15). As time goes by, this settlement developed steadily and then extended until Pal IX Village.

There are many dwellings belong to Bugis descendants at Pal IX Village. However, just a few dwellings that still manage to maintain the physical condition like they were built by the Bugis descendants from South Sulawesi. On Sungai Kakap Street, Pal IX Village, Sungai Kakap Sub-district, and Kubu Raya Regency (look at Figure 1), it can be found three dwellings which were built by the third generation of Bugis descendants. There are two dwellings which are still well-maintained by the owners and one dwelling which is unfortunately not in a good shape. The mass configuration of these dwellings has the similar characteristics as their origin. Therefore, these dwellings will be very interesting to be researched further to understand how Bugis people preserved their culture while adapted to the local culture by comparing them with Bugis dwellings in South Sulawesi.

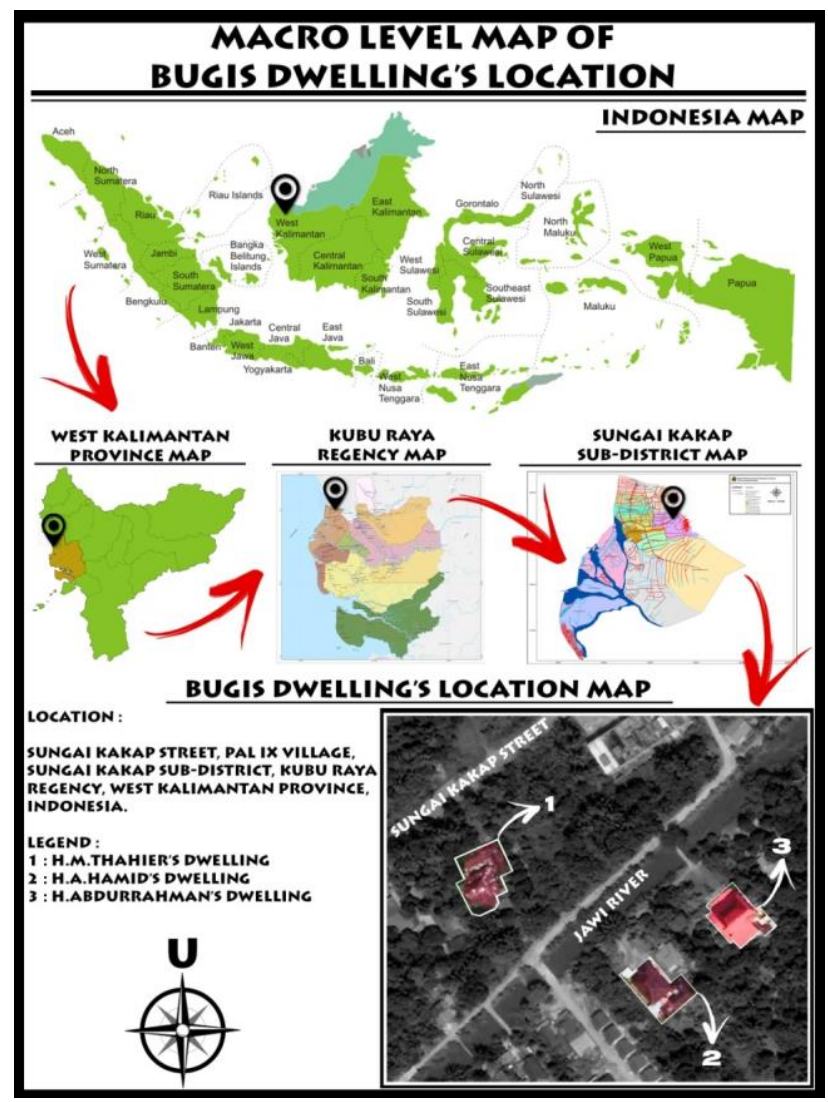

Figure 1: The Map Location of Bugis Dwellings in Kubu Raya

Source: Author

\section{Research Method}

The analytical method used in this research is a comparative method. This research compared the mass configuration, space arrangement, and function of Bugis dwellings in Kubu Raya with the those in South Sulawesi. Those parameters were taken from a research conducted by Akbar (2007) under the title of "The Factors of Characteristics Forming in Traditional Architecture Dwellings of Bugis Nobility in South Sulawesi". 
Submitted: 12 September $2019 \quad$ Accepted: 1 December $2019 \quad$ Published: 31 December 2019

The first step of this research was collecting the primary data i.e. the floor plan of research objects to identify the configuration of its mass, space arrangement and how they use every space on those dwellings. The secondary data in this research was related to the history and the culture of Bugis in Kubu Raya and South Sulawesi.

\section{Literature Review}

Akbar (2007) explains that there is a system of social stratification in Bugis communities. Generally, Bugis social stratification is divided into three parts: Ana'Arung (nobility), To-Maradeka (commoners), and Ata' (slave). These stratifications are then divided into sub-sections based on the area which has their own specific classification. Bugis area can be classified into two types according to the occupation of its inhabitants. The first type is an agricultural area that many inhabitants choose to be Pallaon-ruma (farmers). The second type is the coastal area where the majority of its inhabitants work as Pakkaja (fishermen who sail and fish on the sea) and Pasompe' (nomads who sell carry goods from island to island).

Akbar (2007) also concluded that within the Bugis community, there is a relationship between the social strata and the mass configuration of their homes. Based on the space configuration, it was found that the site of the dwellings which has a large areas has asymmetrical shape and tends to follow the pattern of traditional Bugis buildings. This layout is a form of Bugis aristocratic culture with a close kinship. It means that the residents who live in a house not only consist of nuclear families, but also their closest relatives and servants. Whereas on a narrow areas, the outer layout of the building is symmetrical and elongated (see Figure 2).

Generally, in traditional dwellings of Bugis aristocracy in the past time, the asymmetrical building mass was used by the people from highest degree nobility who had the extra room larger than the lower's one. Therefore, the spatial pattern also acted as a symbol of nobility degrees of the dwelling's owner. Meanwhile, the symmetrical shape was applied on limited and lengthwise site so it formed a linear and lengthwise space adapted to the shape of the site. These conditions were usually utilized to optimize the limited site. Nonetheless, this type of dwellings had a space separation system for the members of the nuclear family and the servants. The nuclear family used the front side of the rooms while the servants used the back one. Therefore, it can be concluded that the living habits of nobility who was served by servants also applied in all spatial forms, both asymmetrical and symmetrical shaped buildings. 


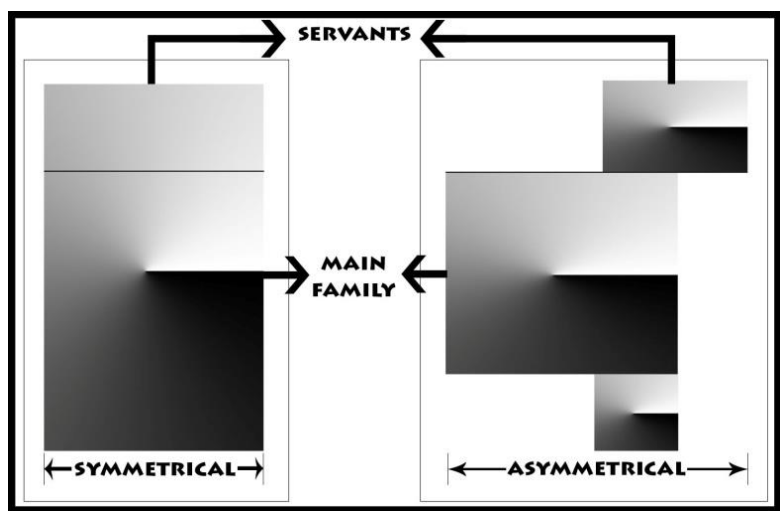

Figure 2: The Configuration of Dwellings Form Based on The Site Area and The Pattern of Space Separation System in Traditional Architecture Dwellings of Bugis Nobility in South Sulawesi

Source: Author

According to Sure' La Galigo, Bugis people consider the role of dwelling not only for protecting human against nature, but also for the unity of life values, physical and spiritual rules. These roles have been implied in the existence of a dream as well as their wish for the survival of the world and the hereafter, prosperous and safe life (Mattulada in Akbar, 2007).

Akbar (2007) also states that Bugis traditional houses are different from one another due to the influence of social strata, which is better known as caste in the teachings of Hinduism and Buddhism. This difference is manifested in the main building's layout of a traditional Bugis house, namely Ale Bola (the middle layer space on the horizontal arrangement). In Ale Bola of Bugis house, there is a room called Lontang which means the distance between pillars in the room. The shape and function of Lontang in the house of nobility and ordinary people mostly are the same. The only thing that distinguishes these houses is their size. The space arrangement in Ale Bola is divided into three zoning:

- Front Room / Lontang Risaliweng: The room which has a function as a place to receive guests, set guest beds, hold meetings, and lay dead bodies if there are family members who passed away.

- Central Room / Lontang Ritengngah: The room which is used as a bedroom for the head of the family, his wife and children. The family members usually utilize this room as a dining room, and mothers use it as a delivery room when giving birth.

- Back Room / Lontang Rilaleng: this space is only used for the elderly parents.

In addition, there is also a room which is called Lego-Lego. This space is located on the frontside of the building that functions as patios or relaxing room. Moreover, the additional space on the backside of the main building is called Jongke. It is usually used as a service room such as a kitchen or warehouse. 


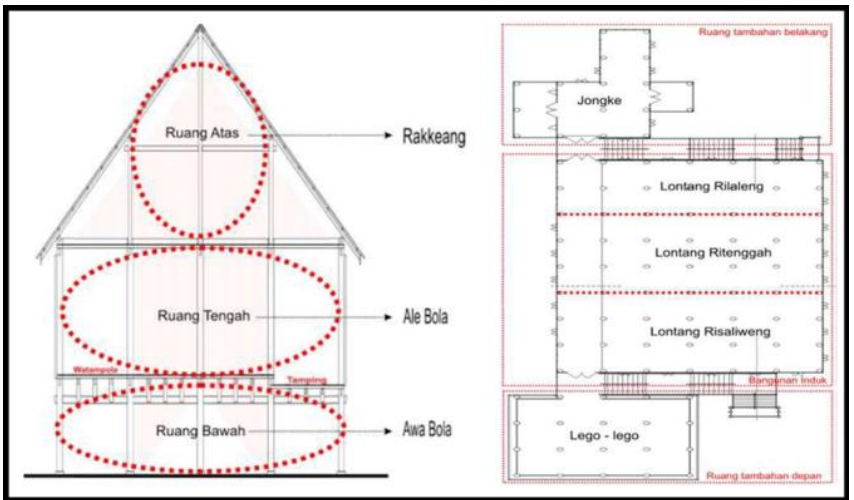

Figure 3: The Concept of Vertical and Horizontal Spaces of Traditional Architecture Dwellings of Bugis Nobility in South Sulawesi

Source: Author

\section{Result}

The object of this research is three Bugis tribe houses that are more than 100 years old. The location of the three houses is adjacent to each other on the Sungai Kakap Highway, Pal IX Village, Kubu Raya, West Kalimantan. The three houses were once established by third generation Bugis born in Pontianak and settled there. In the present, these houses are owned by the descendants of the four Bugis tribes who on average are $70-80$ years old. 


Submitted: 12 September $2019 \quad$ Accepted: 1 December $2019 \quad$ Published: 31 December 2019

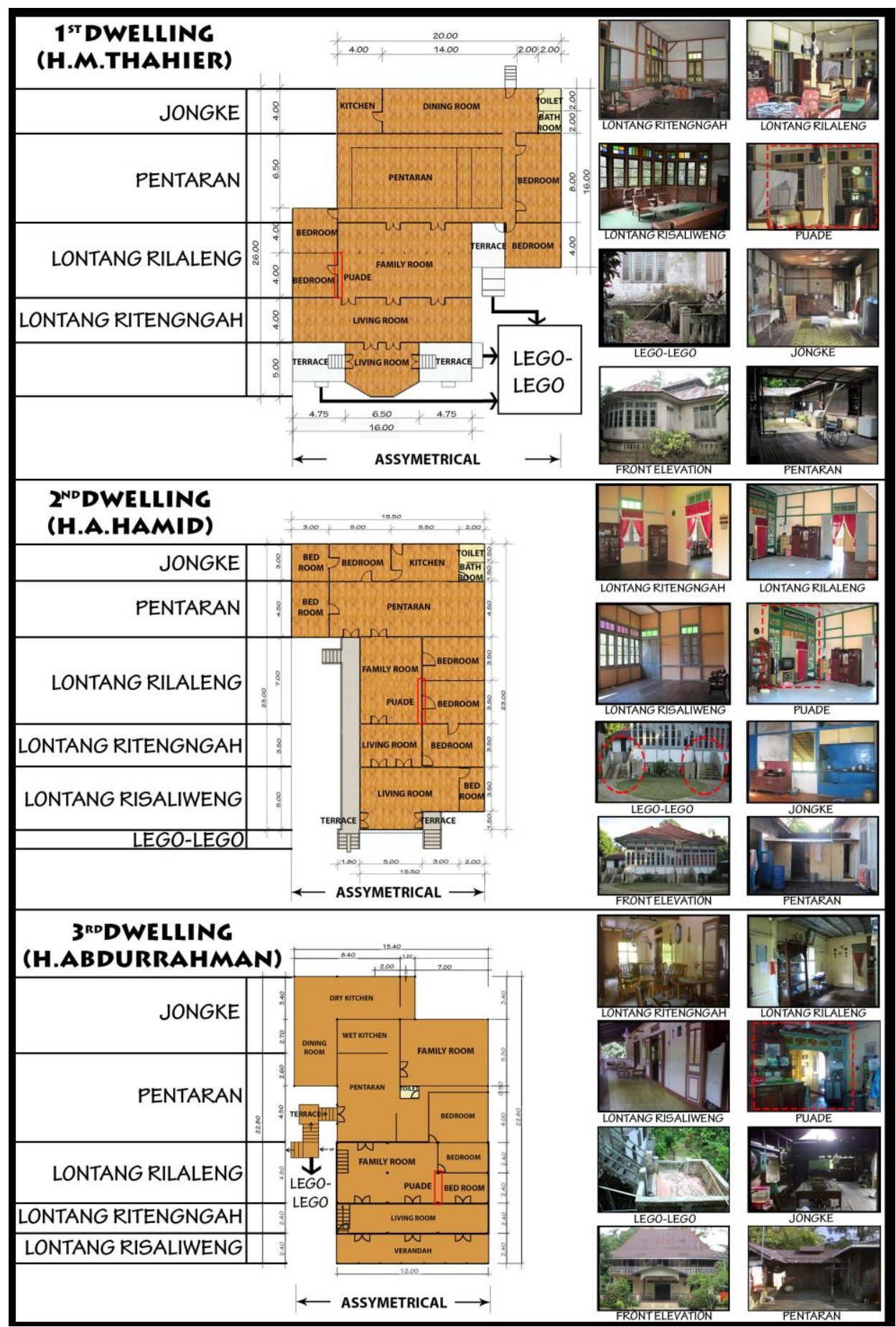

Figure 4: Bugis Dwellings in Kubu Raya

Source: Author

The building configuration of the three Bugis dwellings studied in Pontianak has the same asymmetrical pattern as the dwellings of the Bugis nobility in South Sulawesi (see Figure 4). According to Akbar (2007), this configuration represents the customs of Bugis nobility. This is definitely noticed from the residents living in the house of the Bugis nobility in South Sulawesi. They are not only consist of a nuclear family but also siblings and servants. The noble house usually has an additional room 
that is larger than the room in an ordinary class house. Therefore, it can be concluded that the pattern of the room is also an identity symbol that shows the degree of a nobility of the owner of the building.

The first house was built by the late H.M.Thahier. Based on the result of the interview with his grandson, it was found that Mr. Thahier was not Ana'-Arung (nobility). He was only a To-Maradeka (commoner) who had a high financial capability at that time and could afford to build a dwelling like Bugis nobility's in South Sulawesi. Moreover, he also lived with his extended family and closest relatives, so the need for adequate rooms was relatively high. Therefore, most of the rooms in this dwelling are large due to the size of the family.

Based on the parameters used in this research, the Bugis dwellings in South Sulawesi have Indo Bola (Lontang Risaliweng, Lontang Ritengngah, and Lontang Rilaleng) which is equipped with Lego-Lego and Jongke. The first sample dwelling in Kubu Raya has all of the Indo Bola. Lego-Legos in this house function as a verandah to welcome guests and is well-arranged with a good balance at both sides of Indo Bola. Those Lego-Legos are directly connected with Lontang Risaliweng which functions as a living room.

In addition, Indo Bola in the first sample dwelling includes Lontang Risaliweng, Lontang Ritengngah and Lontang Rilaleng. Between Lontang Rilaleng and Jongke, there is a room called Pentaran which is an inner court used as a transition space. Pentaran cannot be found in Bugis nobility's dwellings, but it is common to be found in Malay House in Pontianak. Malay people call this room Pelataran. This first dwelling also has a space which is marked with a partition full of ornament called Puade which functions as a background for the wedding ceremony. This Puade room is located in Lontang Rilaleng, even though there is no such room like this in Bugis nobility's dwellings in South Sulawesi.

The same case also happened in the second sample house which was built by the late H.A.Hamid bin H.A.Rasjid. The mass configuration of this house is also asymmetric. Based on the interview with his granddaughter who currently lives in this dwelling, it was stated that her grandfather was also not Ana'-Arung (nobility). Mr. Hamid was To-Maradeka (commoner) who had enough wealth to build a dwelling similar to the nobles' in South Sulawesi. In Figure 4, it can be seen that this dwelling also has Lego-Lego, Indo Bola (Lontang Risaliweng, Lontang Ritengngah, and Lontang Rilaleng), and Jongke. Lego-Lego is located at both sides of Indo Bola. One of Indo Bola side is connected to Lontang Risaliweng and the other one is connected to Pentaran. This second dwelling includes Puade in its Lontang Rilaleng which also used for the wedding ceremony with different kind of ornaments.

The third sample dwelling which was once built by the late H.Abdurrahman also has an asymmetric configuration. Even though there is no strong evidence to prove it, this configuration might explicate that the founder was a nobility. However, the fact which can be ascertained is that Mr. Abdurrahman was a landlord who had a thousand hectares of land at that time. Therefore, the researcher can also conclude that her grandfather might be a To-Maradeka (commoners) who had a high financial capability to build a dwelling like Ana'-Arung in South Sulawesi.

The third dwelling has all of the rooms similar to those in Bugis nobility's dwellings in South Sulawesi. This third sample dwelling has Indo Bola, Lego-lego and also Jongke. Similar to the other dwellings, Indo Bola in this third house also consists of Lontang Risaliweng, Lontang Ritengngah and Lontang Rilaleng. Lego- 
Submitted: 12 September $2019 \quad$ Accepted: 1 December $2019 \quad$ Published: 31 December 2019

Lego is located at the side of Indo Bola which is connected with Pentaran. In addition, Puade with a partition full of ornament also can be found in this third dwelling.

\section{Conclusion}

Based on the results of the study, it can be inferred that the mass configuration of the houses belonging to the Bugis descendants in Kubu Raya has similarities and also differences when compared to the mass configuration of the Bugis houses in South Sulawesi. Bugis houses for nobility (Ana'-Arung) in South Sulawesi have an asymmetrical configuration that reflects the manifestations of their habits. The three Bugis houses located in Pontianak which were used as research samples in this study also had the asymmetrical configurations. However, none of the founders of these houses was Ana'-Arung (nobleman). The three founders were To-Maradeka (commoners) who were so prosperous so they could build residential houses like those owned by Bugis nobles in South Sulawesi.

The spatial layout of Bugis dwellings in Kubu Raya not only has similarities, but also differences with the organisation of Bugis nobility dwelling in South Sulawesi. Bugis nobility dwelling in South Sulawesi has a concept of vertical and horizontal spaces. Vertically, it consists of Rakkeang, Ale Bola and Awa Bola while horizontally, it consists of Lego-Lego, Indo Bola (Lontang Risaliweng, Lontang Ritenggah, Lontang Rilaleng) and Jongke. The concept and function of the rooms are similar to all samples. However, there are two differences in terms of space. In all samples, there is a space called Pentaran which is an open space with a void and acts as a transition room between Lontang Rilaleng and Jongke. This kind of space can be found in Malay House in Pontianak. It happened because of Bugis descendant's way of adaptation to the local culture. It indicates that there is an assimilation between these two cultures, Bugis and Malay.

\section{Acknowledgments}

The researcher wants to express her deepest appreciation to all of the interviewees for their sincerity and kindness so this research could be conducted. The researcher also gratefully acknowledge the guidance and support from all of the lecturers in the Department of Architecture, Faculty of Engineering, University of Tanjungpura. The last but not least, the gratitude is also expressed for her family for their support and unconditional love. 
Borneo Journal of Social Science \& Humanities

DOI: https://doi.org/10.35370/bjssh.2019.1.2-05

e-ISSN: 2682-8235

(C) 2018, UCTS Publisher.

Submitted: 12 September 2019 Accepted: 1 December 2019

Published: 31 December 2019

\section{References}

Akbar, A.M. 2007. The Factors of Characteristic Forming in Traditional Architecture Dwellings of Bugis Nobility in South Sulawesi. Case Study: Bugis Nobility Dwellings in Bone, Sidrap and Wajo. Yogyakarta: Gadjahmada University.

Listiana, Dana. 2006. Pontianak Market Development as the Center of Economy Afdeelingshoofdplaats Pontianak (1918-1942). Jatinangor: Padjadjaran University.

Purwana et al. 1999. The History of Pontianak City Government from Time to Time. Pontianak: Romeo Grafika.

Nurcahyani et al. 1999. Pontianak City As a Trading Port on the Silk Road. Jakarta: Ilham Bangun Karya.

Tantra, Nur Andi. and Rahman, Rifai. 2010. Pontianak City Government from Sultanate to City. Pontianak: Lentera Community. 